\title{
Varicella Pneumonia with Acute Kidney Injury in an Immunocompetent Host
}

\section{Ritesh and Harsh Mohinder Singh}

Department of Paediatrics, ITFH, Bokhtar City, Tajikistan

\section{Correspondence: \\ Ritesh \\ Department of Paediatrics, \\ India Tajikistan Friendship Hospital, \\ Bokhtar City, Tajikistan \\ Email: ritesh2000sriji@yahoo.com}

DOI: $10.3126 /$ jnps.v41i2.37136

Submitted on: 2020-08-06

Accepted on: 2021-02-26

Acknowledgements: None

Funding: Nil

Conflict of Interest: None declared

Permission from IRB: Yes
To cite this article: Ritesh, Singh HM. Varicella Pneumonia with Acute Kidney Injury in an Immunocompetent Host. J Nepal Paediatr Soc. 2021;41(2):302-5.

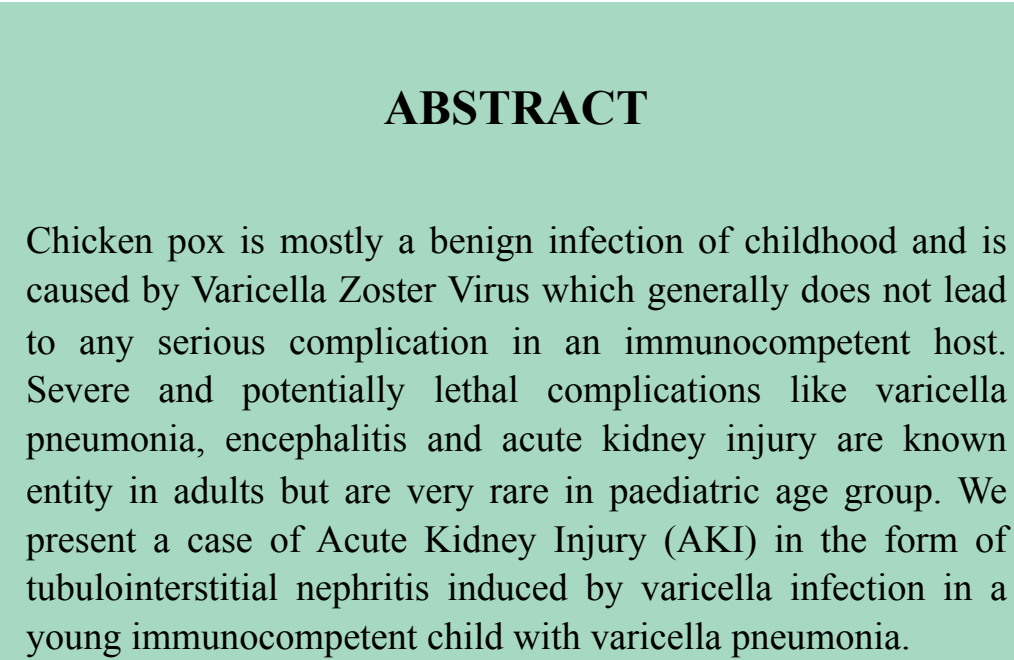

Key words: Acute Kidney Injury; Tubulointerstitial nephritis; Varicella pneumonia

This work is licensed under creative common attribution 3.0 license 


\section{INTRODUCTION}

Varicella is mostly a self-limited benign disease with a very high secondary attack rate. ${ }^{1}$ A large study of Asia pacific region reported the annual incidence of varicella from 17.8 to $323 / 100,000$ populations. $^{2}$ Varicella is known to cause various systemic and local complications like pneumonia, AKI (Acute kidney injury), vasculopathy, encephalitis, cerebellar ataxia, retinal necrosis, otitis media, myocaditis, hepatitis, pancreatitis, cellulitis and necrotising fasciitis with varying incidences and mortality as high as $6 \% .{ }^{3,4}$ Renal involvement in varicella was first reported by Henoch in $1884 .{ }^{5}$ Varicella pneumonia with AKI is rare but a dreaded complication which proved fatal in our case.

\section{CASE REPORT}

A six year old previously healthy girl child presented on tenth day of illness with classic presentation of chicken pox related post viral pneumonia and AKI. At presentation she was febrile and anuric with altered sensorium and also had respiratory distress (Respiratory rate $-36 /$ minute and $\mathrm{SpO}_{2}-94 \%$ with oxygen by mask). BCG scar was present. Fine crackles were heard all over the lung fields. Blood examination showed neutrophilic leucocytosis (TLC - 23,300 / $\mathrm{mm}^{3}$; neutrophils - $87 \%$; lymphocytes- $10 \%$; monocytes $01 \%$ ). Renal functions were grossly deranged (Urea - $194 \mathrm{mg} / \mathrm{dl}$, creatinine - $10.7 \mathrm{mg} / \mathrm{dl}$, estimated GFR by Schwartz formula was: $5.91 \mathrm{ml} / \mathrm{min} / 1.73 \mathrm{~m}^{2}$ ) along with hyperkalemia (Potassium - $7.6 \mathrm{mEq} / \mathrm{L}$ ). Arterial blood gas analysis revealed severe

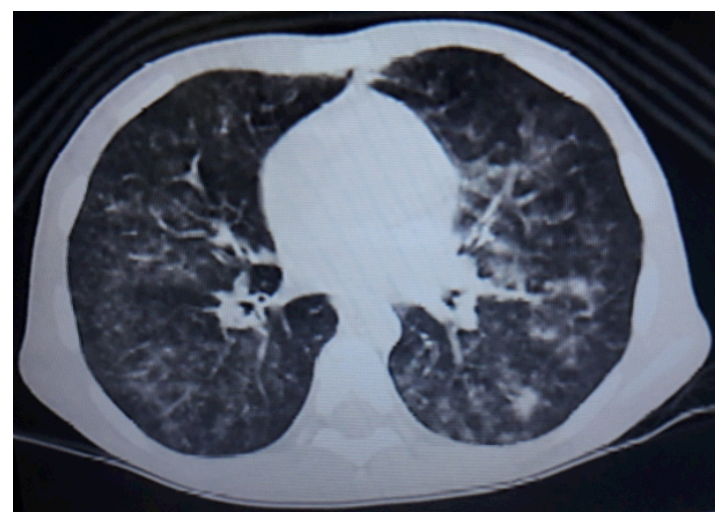

Figure 1. Computed Tomography of chest showing bilateral widespread regions of ground glass opacities metabolic acidosis (pH- 7.008, $\mathrm{HCO}_{3}-5.5 \mathrm{mEq} / \mathrm{L}$, $\mathrm{PaCO}_{2}-18.3 \mathrm{mmHg}$ ). Chest $\mathrm{X}$-Ray showed bilateral non-homogenous opacities fanning two third lung parenchyma centrifugally. Bilateral widespread regions of ground glass opacities and ill-defined centrilobular nodules were seen on computed tomography (CT) of chest (Figure. 1).

Increased renal cortical echogenicity of both the kidneys with hepato-splenomegaly were noted on ultrasonogram. Blood, urine and nasal swab culture were sterile. An initial diagnosis of varicella with secondary infection causing MODS (Multiple organ dysfunction syndrome) was made. Further work up revealed low complement levels $\mathrm{C}_{3}-68.60$ $\mathrm{mg} / \mathrm{dl}$, normal $\mathrm{C}_{4}-21.80 \mathrm{mg} / \mathrm{dl}$ with negative pANCA and cANCA (Perinuclear and cytoplasmic anti-neutrophil cytoplasmic antibodies respectively).

Renal functions and electrolytes improved after 57 cycles of peritoneal dialysis with $1.5 \%$ of peritoneal fluid. She required three antihypertensive medicines to control her blood pressure below $90^{\text {th }}$ percentile. Simple microscopy of kidney biopsy revealed patchy acute tubular injury in the form of multifocal dense chronic lymphoplasmacytic interstitial inflammation and interstitial edema. Immunofluorescence examination showed linear positivity for $\mathrm{IgG}$, kappa \& lambda light chains along tubular basement membranes. Other parameters on immune staining pattern were negative. The glomerular basement membrane thickness ranged from 229.4 to $300.6 \mathrm{~nm}$ with $20 \%$ focal effacement of visceral epithelial cell foot processes (Figure. 2).

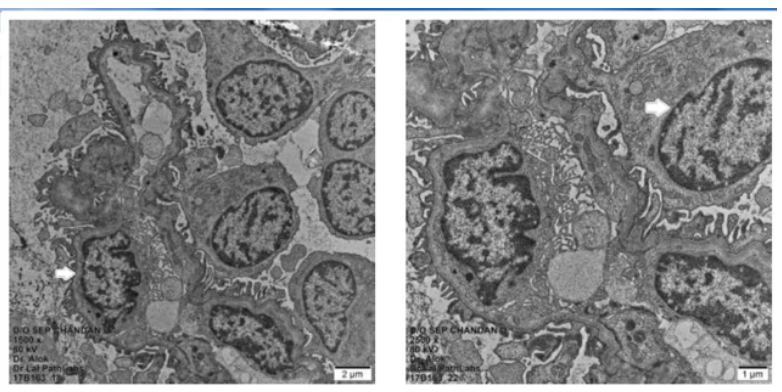

Figure 2. The ultrastructural examination showed glomerular basement membrane thickness with focal effacement of visceral epithelial cell foot 
Table 1. Laboratory parameters during the course of hospitalisation

\begin{tabular}{|c|c|c|c|}
\hline Investigations & $\begin{array}{l}\text { On day of } \\
\text { admission }\end{array}$ & $\begin{array}{c}\text { 9th day of } \\
\text { admission (Kidney } \\
\text { biopsy was done) }\end{array}$ & $\begin{array}{l}17 \text { th day of } \\
\text { admission (Required } \\
\text { ventilator support) }\end{array}$ \\
\hline Haemoglobin (gm/dl) & 10.1 & 8.4 & 7.9 \\
\hline $\begin{array}{l}\text { Total Leucocytes count } \\
\text { Neutrophils } \\
\text { Lymphocytes } \\
\text { Monocytes } \\
\text { Eosinophils }\end{array}$ & $\begin{array}{r}23,300 / \mathrm{mm}^{3} \\
87 \% \\
10 \% \\
01 \% \\
02 \%\end{array}$ & $\begin{array}{r}11,600 / \mathrm{mm}^{3} \\
59 \% \\
35 \% \\
02 \% \\
04 \%\end{array}$ & $\begin{array}{r}19,700 / \mathrm{mm}^{3} \\
88 \% \\
06 \% \\
02 \% \\
04 \%\end{array}$ \\
\hline Platelets & $833 \times 109 / \mathrm{L}$ & $479 \times 109 / \mathrm{L}$ & $395 \times 109 / \mathrm{L}$ \\
\hline Urea / Creatinine (mg/dl) & $194 / 10.7$ & $119 / 3.7$ & $64 / 1.6$ \\
\hline Sodium / Potassium (mEq/L) & $134 / 7.6$ & $140 / 4.5$ & $141 / 5.3$ \\
\hline Calcium (mg/dl) & 8.4 & 7 & 8.4 \\
\hline Alkaline Phosphatase (IU/L) & 238 & 119 & - \\
\hline Protein /Albumin (gm/dl) & $5.9 / 2.1$ & - & $6.1 / 2.1$ \\
\hline Procalcitonin (PCT) & - & - & $0.12 \mathrm{ng} / \mathrm{mL}$ \\
\hline C- reactive protein (CRP) & - & - & $5 \mathrm{mg} / \mathrm{L}$ \\
\hline $\begin{array}{l}\text { Compliment } C_{3}: 68.60 \mathrm{mg} / \mathrm{dl} \text { (low) } \\
\text { Compliment } C_{4}: 21.80 \mathrm{mg} / \mathrm{dl} \text { (Normal) } \\
\text { pANCA (perinuclear Anti-neutrophil cytoplasmic antibodies) } \\
\text { cANCA( cytoplasmic Anti-neutrophil cytoplasmic antibodies) }\end{array}$ & $\begin{array}{l}\text { - Negative } \\
\text { - Negative }\end{array}$ & & \\
\hline
\end{tabular}

The raised leucocytes along with its differential counts returned to normal but after $17^{\text {th }}$ day of management it started rising (Table 1).

The child remained febrile and oxygen dependent. Graded oxygen therapy was instituted and acyclovir along with antibiotics in renal adjusted doses was administered as per hospital policy. Her respiratory parameters continued to worsen. She did not respond while on ventilator support and succumbed to her illness.

\section{DISCUSSION}

Complications of varicella are severe in immunocompromised individuals like pregnant women, elderly and infants. ${ }^{6}$ Healthy children are less prone for have serious and potentially lethal complications but multi organ involvement irrespective of immune status is not a rarity in paediatric age group. Similar to this case renal involvement leading to AKI with varicella pneumonia has been described in adults. ${ }^{7}$

Varicella pneumonia is one of the serious complications presenting in a healthy child. ${ }^{8}$ Mortality rate among children with varicella pneumonia varies and has considerably decreased in post vaccination era. ${ }^{9}$ In our case, clinical and laboratory findings at presentation rendered the possibilities of septicaemia, varicella pneumonia, or pulmonary edema due to AKI. The raised leucocyte count returned to normal but started rising after $17^{\text {th }}$ day of hospitalisation (with negative $\mathrm{C}$ reactive protein and procalcitonin) while on adequate antibiotic cover, refuting the possibility of secondary bacterial affection as the blood and other body fluid cultures also remained sterile. CT chest was also convictive of a viral etiology. 
Various associations of kidney injury have been reported in varicella infection. In this case, though there was neutrophilic leucocytosis but negative culture reports disfavour sepsis causing AKI, more so the child was hypertensive at presentation. Renal biopsy showing a lymphoplasmacytic infiltration instead of a mononuclear response along with negative blood culture also contradicted sepsis related renal damage. Acute tubulointerstitial nephritis is known to happen by many virus infections including herpes group of viruses. It can be caused by immunological response even in absence of direct invasion of viruses. About $1 \%$ cases of acute interstitial nephritis may progress to acute renal insufficiency. Nephrotoxic drugs like Acyclovir may cause acute tubulointerstitial nephritis but in this case the child had not received it prior to onset of AKI. The possibility of renal tubular damage secondary to varicella infection is high on cards in this case, though the mechanism remains arguable. AKI caused by acute tubular necrosis secondary to hypovolemia in varicella infection is known in adult patients. ${ }^{10}$ Presence of plasma cells in interstitium rears a doubt of drug induced allergic nephritis of acyclovir but eosinophil counts were always within the normal range in our case. The values of complement levels suggested immune complex mediated renal injury. However, immunofluorescence examination of kidney biopsy did not show glomerular immune deposition of IgG or C3. Microscopic examination of urine showed the presence of granular cast, characteristic of glomerular basement membrane injury but the histopathological findings of kidney biopsy suggested tubulointerstitial nephritis, possibly caused by a viral etiology.

\section{CONCLUSIONS}

We conclude that varicella infection in paediatric age group may present with utmost severity regardless of immune status of host. Acute tubular injury induced by varicella infection leading to AKI is a rare entity. Early recognition and prompt institution of appropriate management can restore normal renal function.

\section{REFERENCES}

1. Singh M P, Chandran C, Sarwa A, Kumar A, Gupta M, Raj A, et al. Outbreak of chickenpox in a Union Territory of North India. Indian J Med Microbiol. 2015;33:524-7. DOI: 10.4103/0255-0857.167335.

2. Anne ENG, Eun HC, Kulkanya C, Jaydeep C, Barbara K, Ping-Ing L, et al. Burden of varicella in the Asia-Pacific region: a systematic literature review. Expert Rev Vaccines. 201918(5):475-93. DOI: 10.1080/14760584.2019.1594781.

3. Kole AK, Roy R, Kole DC. An observational study of complications in chickenpox with special reference to unusual complications in an apex infectious disease hospital, Kolkata, India. J Postgrad Med. 2013;59:93-7. DOI: $10.4103 / 0022-3859.113811$.

4. Cameron JC, Allan G, Johnston F, Finn A, Heath PT, R Booy. Severe complications of chickenpox in hospitalised children in the UK and Ireland. Arch Dis Child. 2007;92(12):1062-6. DOI: 10.1136/adc.2007.123232.

5. Henoch E. Nephritis nach Varicellen. Berl Klin Wo-chenschr. 1884;21:17.

6. John TD, Zoe MR, Valerie AM, Julia ED, Christine HF, Sajjad I, et al. Varicella Pneumonia: Case Report and Review of a Potentially Lethal Complication of a Common Disease. J. Investig. Med. High Impact Case Rep. 2018;6:1-7. DOI: 10.1177/2324709618770230.

7. Feng-Rong C, Chih-Hsiung L, Chung-Hua C, Wen-Chin L, Chih-Chao Y, Te-Chuan C, et al. Varicella-Zoster Infection with Encephalopathy, Pneumonia and Renal Failure: A Case Report. Renal Failure. 2007;29:359-62. DOI: 10.1080/08860220601166602.

8. Elena B, Guido CG, Mauro B, Nadia M, Marco M, Chiara R, et al. Varicella associated pneumonia in a paediatric population. Ital J Pediatr. 2017;43:49-53. DOI: 10.1186/s13052-017-0366-8.

9. John W G J. Varicella-Zoster Virus: Atypical Presentations and Unusual Complications. J Infect Dis. 2002;186(1): 91-8. DOI: $10.1086 / 342963$. 
10. Vedran P, Marija S, Mario L, Marijana Ć, Bojan J. Acute Kidney Failure as a Single Complication of Varicella Virus Infection in an Adult Patient. Case Rep Nephrol Dial. 2018;8:130-7. DOI: 10.1159/000491627. 